\title{
Modeling the effect of storage temperature on the respiration rate and texture of fresh cut pineapple
}

\author{
S. Benítez ${ }^{a}$, M. Chiumenti ${ }^{b}$, F. Sepulcre ${ }^{a, *}$, I. Achaerandio a ${ }^{a}$ M. Pujolá a \\ a Departament d'Enginyeria Agroalimentària i Biotecnologia, Escola Superior d'Agricultura, Universitat Politècnica de Catalunya, Barcelona, Spain \\ ${ }^{\mathrm{b}}$ Centro Internacional de Métodos Numéricos en Ingeniería (CIMNE), Universitat Politècnica de Catalunya, Spain
}

\section{A R T I C L E I N F O}

\section{Article history:}

Received 19 January 2012

Received in revised form 11 July 2012

Accepted 21 July 2012

Available online 31 July 2012

\section{Keywords:}

Minimal processing

Michaelis-Menten kinetics

Heat transfer

Texture

\begin{abstract}
A B S T R A C T
The effect of temperature on the respiration rate and texture of fresh cut pineapple was studied over the course of 10 days of storage. The thermal exchange between the pineapple trays and the cooling environment was simulated using the finite element method and tested at $6{ }^{\circ} \mathrm{C}$. The temperatures on pineapple wedges differed between the cold point and points near the surface, indicating that the respiration rate may be affected in pineapple subjected to temperature abuse. The experimental respiration rates obtained were used to develop a model relating respiration to $\mathrm{O}_{2}$ and $\mathrm{CO}_{2}$ concentrations at different temperatures using the closed system method. The $\mathrm{O}_{2}$ consumption and $\mathrm{CO}_{2}$ production of pineapple wedges was accurately modeled using Michaelis-Menten kinetics. The texture degradation of pineapple wedges follows a zero-order kinetic reaction at different temperatures and the thermal dependence of the model's parameters for both respiration rate and texture degradation was described by Arrheniustype equations.
\end{abstract}

(c) 2012 Elsevier Ltd. All rights reserved.

\section{Introduction}

In recent years, considerable effort has been made to ensure the quality and safety of minimally processed fruits until they are consumed. Controlling product temperature during refrigerated storage is of critical importance: an optimum temperature maintains the visual quality of fresh cut fruits and reduces their respiration rate, tissue softening and microbial spoilage (Cantwell and Suslow, 2002). A break in the cold chain can lead to a sharp rise in a fruit's respiration rate, affecting the stationary oxygen and carbon dioxide levels inside the package. Therefore, knowledge of the evolution of food products throughout the refrigerated storage process is essential and can be gained through experimental procedures and numerical study. Although experimental research is needed in order to identify real conditions and problems, it can be costly and timeconsuming. Numerical study is an alternative tool that can be used to reproduce refrigerated storage conditions in order to study the influence of different factors on food product preservation.

Pineapple (Ananas comosus) is a non-climacteric fruit appreciated for its flavor, juiciness, texture, and vitamin $C$ and fiber content (Paull and Chen, 2003). However, slicing vegetable tissues leads to an increase in the metabolic process and can result in significant

\footnotetext{
* Corresponding author. Address: Departament d'Enginyeria Agroalimentària i Biotecnologia, Universitat Politècnica de Catalunya, Campus Baix Llobregat, Edifici ESAB-Av. Canal Olímpic, 15, 08860 Castelldefels, Barcelona, Spain. Tel.: +34 93552 1090; fax: +34935521121.

E-mail address: francesc.sepulcre@upc.edu (F. Sepulcre).
}

changes in their textural, color and flavor properties (Del Nobile et al., 2009). The shelf life of fresh cut pineapple is closely tied to its packaging conditions and storage temperature (Soliva-Fortuny et al., 2002).

Selling minimally processed fresh fruit requires a combination of intelligent strategies that extend shelf life while maintaining sensory and organoleptic properties. The main factors that determine the success of a fresh cut fruit product include starting with a high-quality raw material and maintaining the cold chain throughout the manufacturing, distribution and marketing processes (Artés et al., 2007). Modified atmosphere packaging and refrigerated storage are frequently used to reduce the respiration rate without negatively affecting the physiology of the fruit and to increase shelf life (Montero-Calderón et al., 2008). The appropriate gas composition depends on the respiration rate of the produce. Mathematical models have been proposed to correlate the respiration rate with different storage parameters such as gas composition and temperature, but the two factors have rarely been considered simultaneously. Although pineapple is the most commonly consumed tropical fruit in the world, the literature contains few references to the respiration rate of pineapple varieties. The respiration rate of pineapple pulp is twice as high as the whole fruit (Marrero and Kader, 2006). Budu and Joyce (2005) found an exponential relationship between the respiration rate of 'Smooth Cayenne' pineapple slices and $\mathrm{O}_{2}$ and $\mathrm{CO}_{2}$ concentrations at a fixed temperature. On the other hand, Marrero and Kader (2001) reported that the shelf life of the same pineapple variety ranged from a few hours at $20^{\circ} \mathrm{C}$ to over 2 weeks at $0^{\circ} \mathrm{C}$ (in a modified atmosphere) indicating that 


\section{Nomenclature}

a regression coefficient

$b \quad$ regression coefficient

c regression coefficient

$c_{p} \quad$ specific heat, $\mathrm{J} \mathrm{kg}^{-1} \mathrm{~K}^{-1}$

E mean relative deviation modulus, \%

$E_{\mathrm{a}} \quad$ activation energy, $\mathrm{kJ} \mathrm{mol}^{-1}$

$K_{i} \quad$ Michaelis-Menten constant for uncompetitive inhibition, \%

$\mathrm{K}_{\mathrm{mO2}} \quad$ Michaelis-Menten constant for $\mathrm{O}_{2}$ consumption, \%

$K_{m \mathrm{CO} 2}$ Michaelis-Menten constant for $\mathrm{CO}_{2}$ consumption, \%

$k_{p} \quad$ pineapple thermal conductivity, $\mathrm{W} \mathrm{m}^{-1} \mathrm{~K}^{-1}$

A quality factor
$R \quad$ universal gas constant, $8.314 \mathrm{~J} \mathrm{~mol}^{-1} \mathrm{~K}^{-1}$

$R_{\mathrm{O} 2}, R_{\mathrm{CO} 2}$ respiration rate $\left(\mathrm{O}_{2}\right.$ consumption, and $\mathrm{CO}_{2}$ production), $\mathrm{ml} \mathrm{kg}{ }^{-1} \mathrm{~h}^{-1}$

$R_{\mathrm{O} 2 \text { max }}, R_{\mathrm{CO} 2 \max }$ maximum respiration rate $\left(\mathrm{O}_{2}\right.$ consumption, and $\mathrm{CO}_{2}$ production), $\mathrm{ml} \mathrm{kg}^{-1} \mathrm{~h}^{-1}$

T storage temperature, ${ }^{\circ} \mathrm{C}$

$T_{\text {abs }} \quad$ absolute temperature, $\mathrm{K}$

$t \quad$ storage time, $\mathrm{h}$

$\left[\mathrm{O}_{2}\right]$ oxygen concentration, \%

$\left[\mathrm{CO}_{2}\right]$ carbon dioxide concentration, \%

Greek letter $\rho_{p}$ density, $\mathrm{kg} \mathrm{m}^{-3}$ temperature plays a considerable role in the lifespan of the product. Texture is an important attribute that determines consumers' acceptance or rejection of fresh cut fruits (Soliva-Fortuny et al., 2002). Several authors have studied pineapple texture (Eduardo et al., 2008; Gil et al., 2006; Liu et al., 2007; Martínez-Ferrer and Harper, 2005; Montero-Calderón et al., 2010) but no prior research has examined the effect of different storage temperatures on texture. Inadequate temperatures promote tissue softening and juice leakage; therefore, studying the influence of storage temperature on fruit is useful in predicting pineapple firmness.

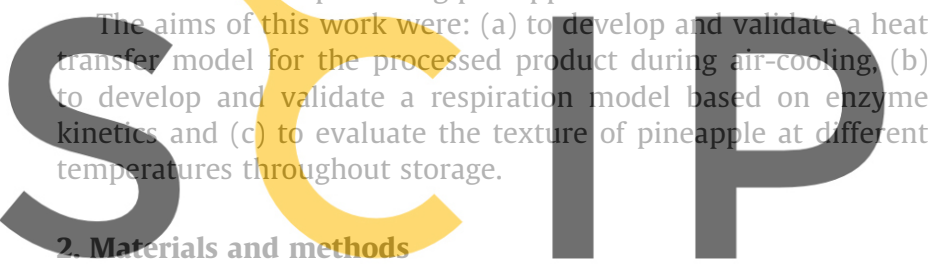

Register for free at https//www.scipedia.com to

2.1.1. Transient heat transfer model during cooling

The heat transfer model is enforced by setting the balance of energy equation

$\rho c_{p} \frac{\partial T}{\partial t}-\nabla \cdot Q=0$

where $\rho$ indicates density $\left(\mathrm{kg} \mathrm{m}^{-3}\right), c_{p}$ is specific heat $\left(\mathrm{J} \mathrm{kg}^{-1} \mathrm{~K}^{-1}\right), t$ is time (s), $T$ is temperature $\left({ }^{\circ} \mathrm{C}\right)$, and $Q$ is thermal flux. The heat flux $Q$ is defined by Fourier's law as:

$Q=-k_{p} \nabla T$

where $k_{p}$ is conductivity $\left(\mathrm{W} \mathrm{m}^{-1} \mathrm{~K}^{-1}\right)$ and $\nabla T=\left[\frac{\partial T}{\partial x} \frac{\partial T}{\partial y} \frac{\partial T}{\partial z}\right]$ is temperature gradient.

The following step is the integration of this equation into the entire domain of the problem, $\Omega$. After applying the weighted residual method, the weak form (global equilibrium) of the problem is stated as:

$\int_{\Omega} \delta \omega r(T) d \Omega=0$

where $r(T)$ is the residual of the balance equation defined as:

$r(T)=C_{P} \frac{d T}{d t}-\nabla Q$

If the Garlerkin method is applied, the arbitrary weight function $\delta \omega$ can be replaced by $\delta T$ and the weak form of the balance of energy equation results in:

$\int_{\Omega} \delta T C_{p} \frac{d T}{d t} d \Omega-\int_{\Omega} \delta T \nabla \cdot Q d \Omega=0$
Integrating the last term in the above expression and taking Fourier's law into account (Eq. (2)), it is possible to write:

$\int_{\Omega} \delta T C_{\text {Piña }} \frac{d T}{d t} d \Omega+\int_{\Omega} \nabla(\delta T) K_{\text {Piña }} \nabla T d \Omega=\int_{\Omega} \Gamma_{q} T \bar{q} d \Gamma$

where $\bar{q}=Q \cdot n$ is the heat flux (Neumann condition) normal to the boundary of the domain, $\Gamma_{q}$. The Dirichlet boundary condition must be considered in terms of prescribed temperature, $T=\bar{T}$ along the $\Gamma_{T}$ boundary. The Neumann boundary condition is also commonly Applying Newton's law, heat convection flux can be expressed as:
$\bar{q}_{\text {conv }}=h_{\text {conv }}\left(T-T_{\text {env }}\right)$
where $T$ is the product surface temperature, $T_{\text {env }}$ is thd environment
temperature and $h_{\text {con, }}$ is the heat convection coeffidienc.
Heat radiation flux can bestated as:

\section{$\bar{q}_{\text {rad }}=\varepsilon \rho_{0}\left(T^{4}-T_{\text {nnv }}^{4}\right.$}

download the version without the watermark where $\varepsilon$ is the emissivity of the material and $\rho_{0}$ is the Boltzmann constant $\left(\mathrm{J} \mathrm{K}^{-1}\right)$

Finaliy, when the initial condition is imposed, the thermal problem is totally defined:

$T(0)=T_{o}$

The following assumptions were made:

(a) The food sample is homogeneous and isotropic.

(b) The initial temperature $\mathrm{T}_{0}$ of the sample is homogeneous.

(c) Heat and mass transport due to moisture surface evaporation is negligible.

(d) The heat generated by respiration of minimally processed pineapple is negligible.

(e) The heat exchange between pineapple and air takes place by natural convection.

The system of unsteady nonlinear partial differential equations was solved by the finite element method (FEM) using the heat transfer module of Profood (CIMNE, Spain). FEM has been successfully used by other authors in the study of food processing and conservation. For example, Itaya et al. (1995) used FEM to model heat and moisture transfer in composite foods during drying, Misra and Young (1979) simulated the cooling of apples, Ngadi et al. (1997) modeled moisture transfer in chicken drumsticks during deep-fat frying, Pan and Bhowmik (1991) analyzed heat transfer in fresh tomatoes during cooling and Wang and Sun (2002) studied the three-dimensional transient heat transfer of roasted meat during air blast cooling. 


\subsubsection{Respiration model}

The respiration rate of fruit tissues refers to a global process that encompasses the diffusion of gases through the tissues as well as respiration at the cellular level (Cameron et al., 1995). Fonseca et al. (2002) reviewed several models that describe the relationship between gas concentrations and the respiration rate of fruit, although enzymatic models have been chosen in many cases (Bhande et al., 2008; Mahajan and Goswami, 2001). Oxygen consumption over time can be expressed using the Michaelis-Menten model

$R_{\mathrm{O}_{2}}=\frac{R_{\mathrm{O}_{2} \max }\left[\mathrm{O}_{2}\right]}{K_{m}+\left[\mathrm{O}_{2}\right]}$

where $R_{\mathrm{O}_{2} \text { max }}$ is the maximum respiration rate and $K_{m}$ is the oxygen concentration at which the respiration rate is half of $R_{\mathrm{O}_{2} \max }$. An uncompetitive $\mathrm{CO}_{2}$ inhibition model (Hagger et al., 1992; Lee and Lee, 1996; Mangaraj and Goswami, 2011; Song et al., 1992) was also fitted to the data to study the possible effect of $\mathrm{CO}_{2}$ concentration on $\mathrm{O}_{2}$ consumption:

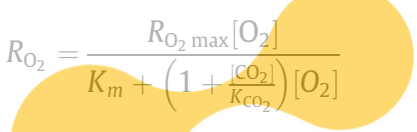

Similar equations can be written for $\mathrm{CO}_{2}$ production. The determination coefficient $\left(R^{2}\right)$ and the mean relative deviation modulus $(E)$ were calculated to evaluate the accuracy of the model. In gen-

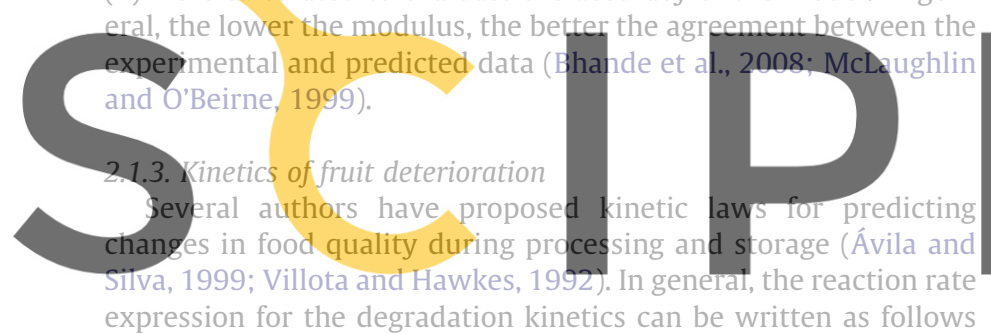

Registerrifofielffeße) at https//www.scipedia.com to dA

$\frac{d A}{d t}=-k A^{n}$

where $A(t)$ is the quantitative value of the texture of the product under consideration, $k$ is the rate constant $\left(\right.$ time $\left.^{-1}\right)$, and $n$ is the order of the reaction. The kinetic constant $k$ is dependent on temperature and this relationship can often be expressed by the Arrhenius equation (Purwadaria et al., 1979; Taoukis et al., 1997). Zero-order or first-order models are frequently reported with regard to changes in foods (Chen and Ramaswamy, 2002). For $n=0$, the relationship between a quality attribute and time is linear; therefore substituting in Eq. (12) yields:

$A=A_{0}-k t$

\subsubsection{Temperature dependence}

The influence of storage temperatures on the respiration rate and texture of fresh cut pineapple was estimated using the Arrhenius equation

$P^{(i)}=P_{\text {ref }}^{(i)} \exp ^{\left(\frac{-E_{\mathrm{a}}}{R T}\right)}$

where $P^{(i)}$ is the parameter value, $P^{(i)}$ ref is the pre-exponential factor, $R$ is the gas constant, $E_{\mathrm{a}}$ is the activation energy and $T_{\mathrm{abs}}$ is the absolute temperature. The Eq. (14) can be expressed in a linear form as shown in Eq. (15):

$\ln P^{(i)}=\ln P_{\mathrm{ref}}^{(i)}-\frac{E_{\mathrm{a}}}{R}\left[\frac{1}{T_{\mathrm{abs}}}\right]$

\subsection{Experimental procedures}

\subsubsection{Preparation of fresh cut produce}

Costa Rican 'Del Monte MD2' type fresh pineapples (A. comosus) without crowns were provided by a fresh-cut company (Barcelona, Spain). The fruit was stored at $7{ }^{\circ} \mathrm{C}$ until processing. The pineapples were immersed in $200 \mathrm{mg} \mathrm{mL}^{-1}$ sodium hypochlorite for $3 \mathrm{~min}$ at $15{ }^{\circ} \mathrm{C}$ (bath and room temperature were the same) and drained. Slices of one centimeter were obtained with a pineapple peeler. The slices were cut into wedges (8-9 g each) with sharp knives. The fruit pieces were carefully mixed and $90 \mathrm{~g}$ of the pineapple wedges were packaged on polypropylene trays $(255 \mathrm{ml})$ with $126.45 \mathrm{~cm}^{2}$ of gas exchange area. The trays were thermo-sealed using a manual sealer (ILPRA Easybox, Ilpra Systems, Italy) with a PET-PP-EVOH-PP film ( $\mathrm{P}_{\mathrm{O} 2}, \mathrm{P}_{\mathrm{CO} 2}<1 \mathrm{ml} \mathrm{m}^{2} \mathrm{~d}^{-1}$ bar $^{-1}$, thickness $0.85 \mathrm{~mm}$ ) and kept at 4,7 and $13 \mathrm{C}$ for up to 10 days. Initial total solid soluble content and titratable acidity (citric acid) were $12-14{ }^{\circ} \mathrm{Brix}$

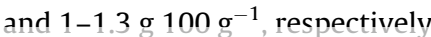

\subsubsection{Temperature measurement}

To acquire experimental data and to validate the heat transfer model, different experiments were performed using minimally processed pineapple packaged on polypropylene trays. Five copper-constantan thermocouples (TC Direct, Spain) were used to measure both the temperature evolution of the pineapple wedges at the cold point and the ambient temperature. The thermocou-

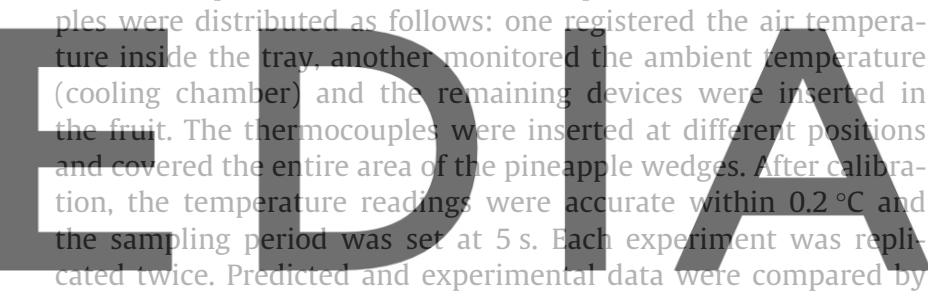
calculating the root mean square error (RMSE) as suggested by

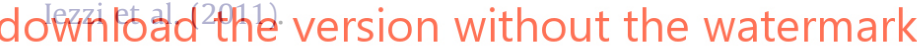

\subsubsection{Respiration measurement}

The respiration rates of pineapple wedges were measured using a closed system method (Hong and Kim, 2001; Lee et al., 1994; Yam et al., 1993). Approximately $200 \mathrm{~g}$ of pineapple was placed in $997 \mathrm{ml}$ airtight glass jars containing air as the initial gas atmosphere. The jars were simply closed with metal caps equipped with silicone septums when the target temperature was reached. Sampling of the headspace gas concentrations was terminated when the level of $\mathrm{CO}_{2}$ inside the jars reached approximately $20 \%$, as the enzymatic model is valid only for aerobic respiration. Headspace $\mathrm{O}_{2}$ and $\mathrm{CO}_{2}$ gas concentrations in individual jars were monitored using a Checkmate II gas analyzer (PBI Dansensor, Denmark). Gas samples were taken by inserting a needle through the septum attached to the lid of the jars. Gas readings were taken continuously until stable data were displayed on the screen. To avoid modifications in the headspace gas composition and pressure due to gas sampling, a return needle was also attached to the septum. Typically, the samples were taken every hour for the first six hours, then every nine hours and finally every day. Changes in $\mathrm{O}_{2}$ and $\mathrm{CO}_{2}$ concentrations were used to estimate respiration rates according to Eqs. (10) and (11). Experiments were conducted at 2, 4, 7 and $13^{\circ} \mathrm{C}$ and the determinations at each temperature were conducted in quadruplicate. The free volume of the jars (Table 1) consisted of the total volume of the jars minus the volume occupied by their content, calculated as a function of the product mass and density $\left(\rho_{p}\right)$. The density was calculated following the method of Choi and Okos (1986) as reported in Section 3.1. 
Table 1

Free volume and weight of pineapple taken for generating the respiration rate ${ }^{\mathrm{a}}$.

\begin{tabular}{lll}
\hline$T\left({ }^{\circ} \mathrm{C}\right)$ & Weight of pineapple $(\mathrm{kg})$ & Free volume $(\mathrm{ml})$ \\
\hline 2 & $0.202 \pm 0.001$ & $802.98 \pm 1.54$ \\
4 & $0.200 \pm 0.003$ & $804.73 \pm 1.81$ \\
7 & $0.201 \pm 0.001$ & $804.08 \pm 1.86$ \\
13 & $0.198 \pm 0.004$ & $806.56 \pm 3.46$ \\
\hline
\end{tabular}

a Values are average of four replicates.

\subsubsection{Texture measurement}

A minimally processed pineapple texture analysis was performed using a TA.XT2 texture analyzer (Stable Micro Systems, UK) with a $30 \mathrm{~kg}$ load cell. Firmness was measured as the work required to depress $4 \mathrm{~mm}$ into the fruit with a $2 \mathrm{~mm}$ flat head stainless steel cylindrical probe at a speed of $1 \mathrm{~mm} \mathrm{~min}^{-1}$ with automatic return. The work was calculated as the area under the curve until the maximum force recorded in the force-displacement curve. Nine replicates were carried out at 4,7 and $13{ }^{\circ} \mathrm{C}$. Statistical differences were examined by two-way analysis of variance (ANOVA) follow by a Tukey's HSD (Honestly Significant Difference) test to compare means at a significance level of $5 \%$.

\section{Results and discussion}

\subsection{Heat transfer model}

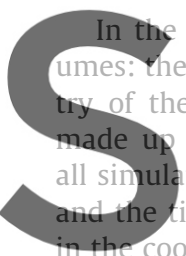
FEM analysis, the domains food, the tray and the surrqun the system was discretized of 53,043 tetrahedral elements ime step was set to $150 \mathrm{~s}$. ling chamber were conducted
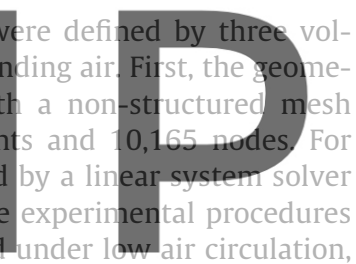

therefore natural convection can be assumed. The heat transfer Registerfor free atqutte the heat convection flux was shows the model for the pineapples wedges inside the thermosealed polypropylene trays and the mesh used to describe the domain. The analysis was performed starting from a uniform temperature throughout the system $\left(14.8^{\circ} \mathrm{C}\right)$ and continuing until it reached the temperature of the cooling chamber $\left(6^{\circ} \mathrm{C}\right)$. The cooling chamber temperature was constant and the cooling cycles were disregarded. The thermal properties $\rho_{p}(T), c_{p}(T)$, and $k_{p}(T)$ used in the simulation were calculated from the formulation proposed by Choi and Okos (1986). For this propose, the composition of pineapple was assumed as: water $85.75 \%$, carbohydrates $14.29 \%$, protein $0.47 \%$, minerals $0.3 \%$, fiber $0.45 \%$ and fat $0.04 \%$, as previously published by Chaiwanichsiri et al. (1996). The average values used were $\rho_{p}=1044.32 \mathrm{~kg} \mathrm{~m}^{-3}, c_{p}=3825.48 \mathrm{~J} \mathrm{~kg}^{-1} \mathrm{~K}^{-1}$ and $k_{p}=0.5464$ $\mathrm{W} \mathrm{m}{ }^{-1} \mathrm{~K}^{-1}$ and were considered independent of temperature in the range $0-20^{\circ} \mathrm{C}$ because no phase change occurred.

Fig. 1b shows the temperature distribution after one hour of aircooling and Fig. 2 shows the predicted and experimental time evolution temperatures at the center and at a border point of the pineapple wedges for the air-cooling experiments. These results show us that the pineapples wedges reached the same equilibrium temperature in $3 \mathrm{~h}$ in both places measured: at the surface and at the center of the wedge, indicating a complete homogeneous temperature distribution inside the pineapple piece after this time. The difference between the typically storage time (days) and the time that the pineapple wedges need to arrive to the equilibrium temperature $(3 \mathrm{~h})$ guarantees that both the respiration and texture measurements are made under steady state conditions.

As shown, the numerical model satisfactorily predicts the temperature evolution of the air cooling process. As expected, the surfaces of the wedges exposed directly to the air have a faster heat exchange rate. The trays of pineapple wedges reached the equilibrium temperature after $3 \mathrm{~h}$ of refrigerated storage.

\subsection{Respiration rate}

The instantaneous respiration rate can be obtained by plotting the gas concentrations inside the jars versus time, but this method is not recommended due to the wide variations in many experimental data. Instead, a regression function is often used to fit the

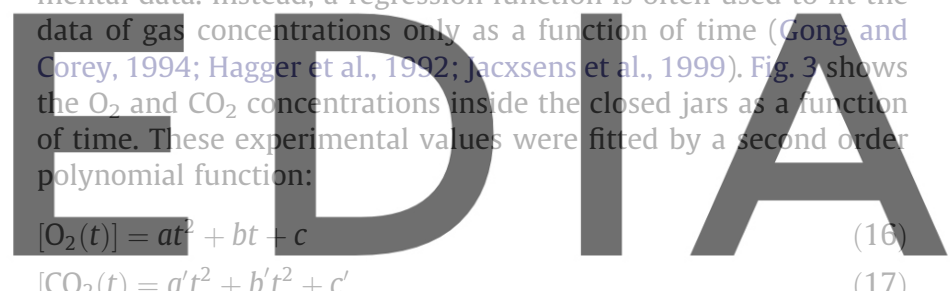

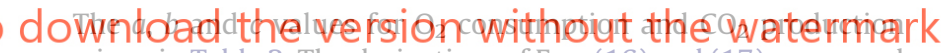
are given in Table 2. The derivatives of Eqs. (16) and (17) were used to calculate the respiration rates following the three step method proposed by Gong and Corey (1994). The respiration rate can be expressed as only a function of gas concentrations:

$R_{\mathrm{O}_{2}}=10 \sqrt{b^{2}-4 a\left(c-\left[\mathrm{O}_{2}\right]\right)} W^{-1} V$

$R_{\mathrm{CO}_{2}}=10 \sqrt{b^{\prime 2}-4 a^{\prime}\left(c^{\prime}-\left[\mathrm{CO}_{2}\right]\right)} W^{-1} V$

Next, the experimental respiration rates obtained from Eqs. (18) and (19) were used to estimate the model parameters of Eq. (10) by means of nonlinear regression with the Levenberg-Marquardt algorithm using MATLAB software ver. 7.11 (Matworks Inc., USA).
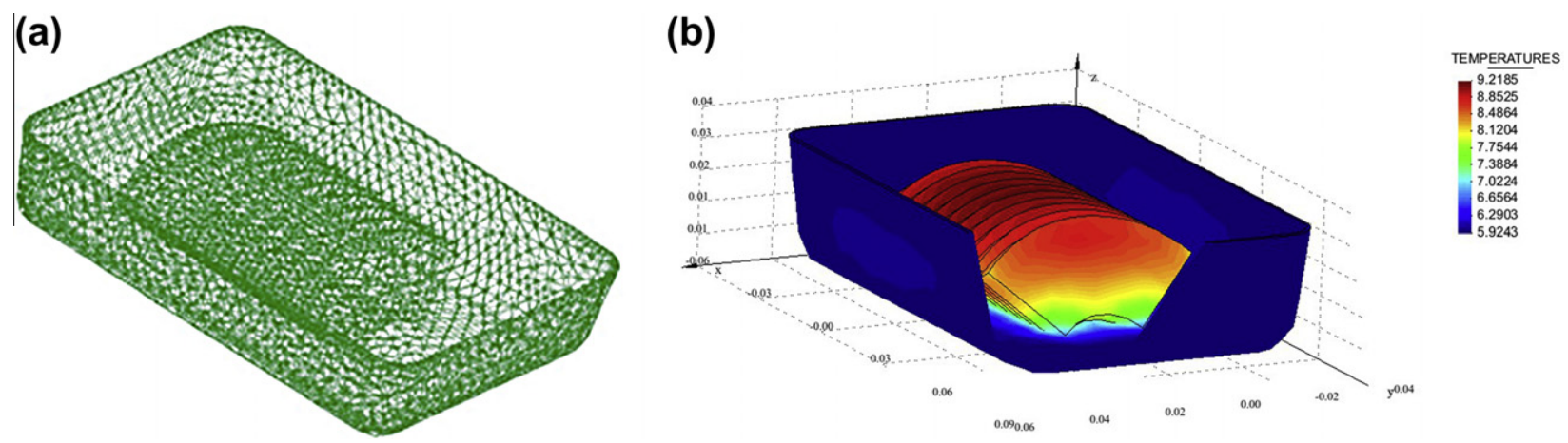

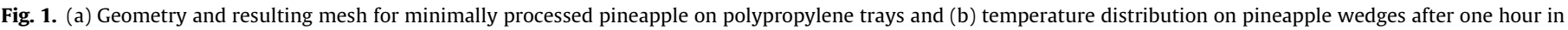
the cooling chamber. 


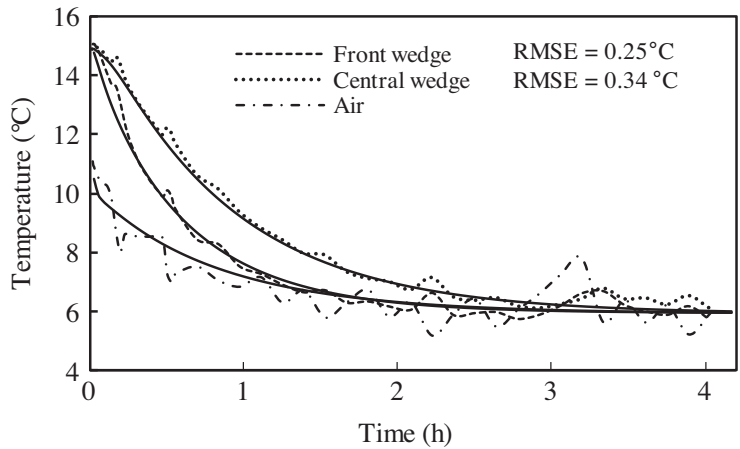

Fig. 2. Experimental and predicted temperatures during the cooling process on the front wedge point $(0,0.02,0.006)$ and on the central wedge point $(0,-0.02,0.02)$. Coordinates are expressed in meters. The continuous lines represent the FEM simulations.

Table 3 presents the values of the model parameters at each temperature. The excellent agreement between the predicted and experimental data verifies the goodness of the model parameters $\left(R^{2}>0.93\right)$. The possible inhibiting effect of $\mathrm{CO}_{2}$ on $\mathrm{O}_{2}$ uptake was studied through Eq. (11). In these studies, the inclusion of parameter $K_{i}$ did not improve the fit of the respiration rates and the confidence intervals were quite high (data not shown). The $\mathrm{O}_{2}$ consumption of about $2.4 \mathrm{ml} \mathrm{kg}^{-1} \mathrm{~h}^{-1}$ at $4{ }^{\circ} \mathrm{C}$ and $10 \% \mathrm{O}_{2}$ (Fig. 4a) is close to the $2.5-3 \mathrm{ml} \mathrm{kg}^{-1} \mathrm{~h}^{-1}$ at $4.5^{\circ} \mathrm{C}$ reported for 'Smooth Cay-

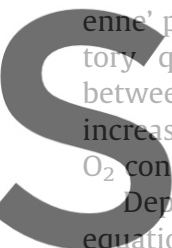
ineapple slices by Budu and

quotients $\left(\mathrm{RQ}=R_{\mathrm{CO} 2} / R_{\mathrm{O} 2}\right)$ for

tween 0.7 and 1.06 depending $c$

creased as $\mathrm{O}_{2}$ concentration decre

Dependence on temperature

on (Eq. (15)) was determined by

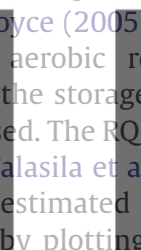

5). Average respira-
respiration janged
ge temperature and
Q depended on both
al., 1992)
d by the Arrhenius
ng the natural logarithm of the model parameters against the inverse of temperature. The resulting linear plot for each parameter, is shown in Fig. 4b.

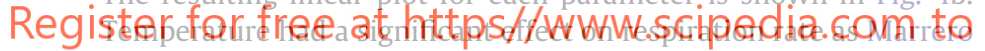
and Kader (2006) have reported in previous studies. Activation energy was calculated from the slope of the line and the pre-exponential factor was calculated from the $Y$-axis intercept. Table 4 shows the activation energy and pre-exponential factors for different model parameters of enzyme kinetics. Activation energy values range from 29 to $93 \mathrm{~kJ} \mathrm{~mol}^{-1}$ for fruits and vegetables (Exama
Table 3

Michaelis-Menten $R_{\max }$ and $K_{m}$ coefficients (95\% confidence interval).

\begin{tabular}{lcccl}
\hline$T\left({ }^{\circ} \mathrm{C}\right)$ & $R_{\mathrm{O} 2 \max }\left(\mathrm{ml} \mathrm{O}_{2} \mathrm{~kg}^{-1} \mathrm{~h}^{-1}\right)$ & $K_{m \mathrm{O} 2}(\%)$ & $E(\%)$ & $R^{2}$ \\
\hline 2 & $4.59 \pm 0.06$ & $17.78 \pm 0.50$ & 0.10 & 0.99 \\
4 & $4.81 \pm 0.12$ & $16.27 \pm 0.80$ & 1.26 & 0.99 \\
7 & $7.61 \pm 0.39$ & $12.88 \pm 1.43$ & 0.99 & 0.99 \\
13 & $16.71 \pm 1.15$ & $12.28 \pm 2.04$ & 0.04 & 0.99 \\
$T\left({ }^{\circ} \mathrm{C}\right)$ & $R_{\mathrm{CO} 2 \max }\left(\mathrm{ml} \mathrm{CO}_{2} \mathrm{~kg}^{-1} \mathrm{~h}^{-1}\right)$ & $K_{m \mathrm{CO} 2}(\%)$ & $E(\%)$ & $R^{2}$ \\
\hline 2 & $3.40 \pm 0.77$ & $2.98 \pm 1.54$ & 14.04 & 0.93 \\
4 & $4.15 \pm 0.70$ & $3.71 \pm 1.53$ & 10.24 & 0.93 \\
7 & $12.40 \pm 1.67$ & $9.70 \pm 2.82$ & 13.37 & 0.98 \\
13 & $29.93 \pm 4.74$ & $8.53 \pm 2.77$ & 15.97 & 0.98 \\
\hline
\end{tabular}

et al., 1993) but can be as high as $136 \mathrm{~kJ} \mathrm{~mol}^{-1}$ (Jacxsens et al., 2000). If we consider that a passive atmosphere modification take place in the pineapple trays it means that the $\mathrm{O}_{2}$ concentration at time zero is $20.8 \%$. Taking into account the temperature evolution profile of the pineapple wedges (Fig. 2) coupled to the MichaelisMenten respiration model, we estimate that in the first three hours of cooling at least a $1.7 \%$ of $\mathrm{O}_{2}$ is consumed.

Model predicted respiration rates of pineapple were verified with experimental respiration rates at $15^{\circ} \mathrm{C}$. This temperature was chosen as it is the average temperature of the acclimated processing room. The $a, b$ and $c$ constants obtained for Eqs. (16) and (17) were $0.001,-0.2863,19.97$ for $\mathrm{O}_{2}$ consumption and 0.004 , 0.1934 and 2.32 for $\mathrm{CO}_{2}$ production with an $R^{2}$ of 0.98 and 0.91 ,

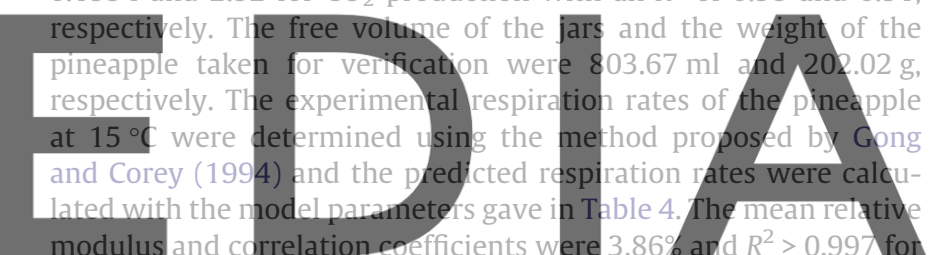

$R_{\mathrm{O} 2}$ and $18.34 \%$ and $R^{2}>0.992$ for $R_{\mathrm{CO} 2}$, thus confirming the predictive ability of the model $(E<20 \%)$

download the version without the watermark 3.3. Texture

Firmness measurements $(\mathrm{N} \mathrm{mm})$ were taken as the area under the curve from 0 to maximum force in the puncture test. Two-way ANOVA showed significant effects of both temperature and storage time, with no cross effect (Table 5). Fig. 5 shows the firmness
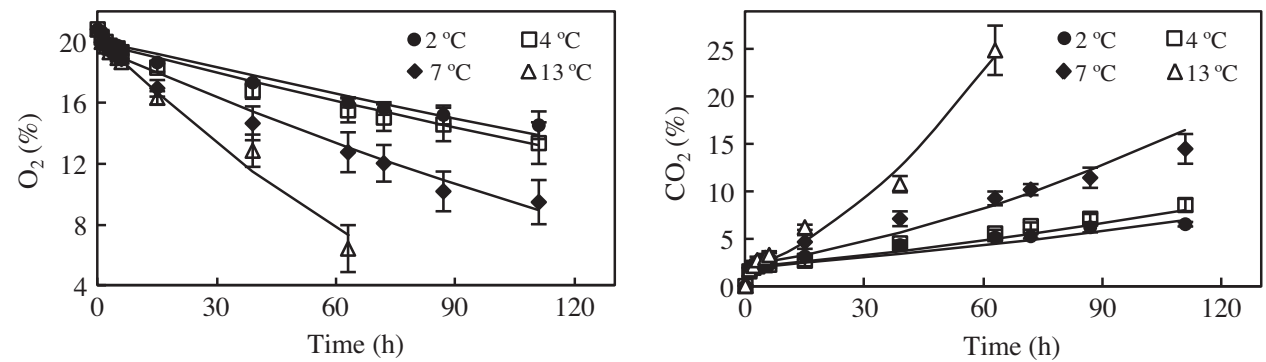

Fig. 3. Changes in gas concentrations inside closed jars containing cut pineapple.

Table 2

Values of coefficients for experimental $\mathrm{O}_{2}$ consumption and $\mathrm{CO}_{2}$ production.

\begin{tabular}{|c|c|c|c|c|c|c|c|c|}
\hline$T\left({ }^{\circ} \mathrm{C}\right)$ & $a \mathrm{O}_{2}$ & $b \mathrm{O}_{2}$ & $c \mathrm{O}_{2}$ & $R^{2}$ & $a^{\prime} \mathrm{CO}_{2}$ & $b^{\prime} \mathrm{CO}_{2}$ & $c^{\prime} \mathrm{CO}_{2}$ & $R^{2}$ \\
\hline 2 & $4.74 \mathrm{E}-05$ & $-6.16 \mathrm{E}-02$ & 20.11 & 0.962 & $1.01 \mathrm{E}-04$ & $3.42 \mathrm{E}-02$ & 1.92 & 0.864 \\
\hline 4 & $5.55 \mathrm{E}-05$ & $-6.62 E-02$ & 19.91 & 0.986 & $1.45 \mathrm{E}-04$ & $3.80 \mathrm{E}-02$ & 2.04 & 0.974 \\
\hline 7 & $1.71 \mathrm{E}-04$ & $-1.16 \mathrm{E}-01$ & 19.67 & 0.982 & $5.47 \mathrm{E}-04$ & $6.82 \mathrm{E}-02$ & 2.14 & 0.979 \\
\hline 13 & $8.23 \mathrm{E}-04$ & $-2.59 \mathrm{E}-01$ & 20.34 & 0.980 & $3.29 \mathrm{E}-03$ & $1.51 \mathrm{E}-01$ & 1.72 & 0.949 \\
\hline
\end{tabular}



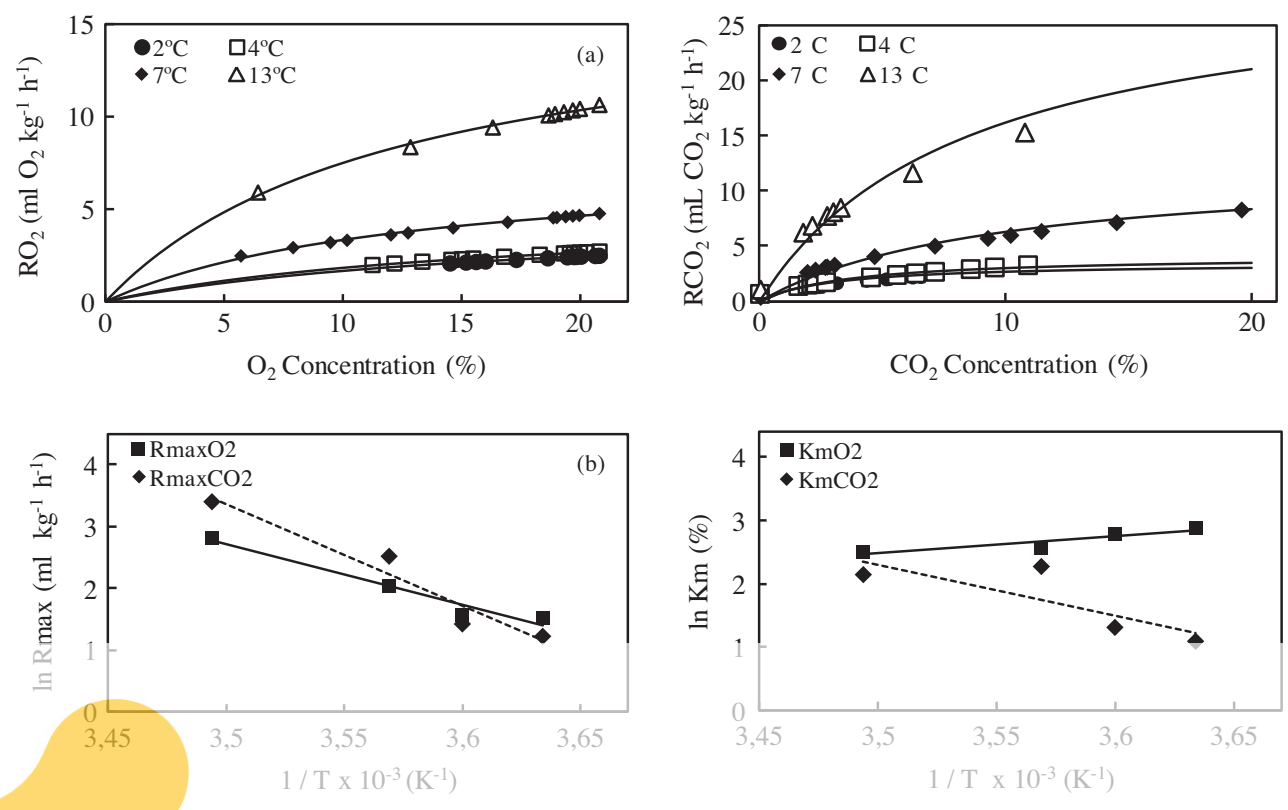

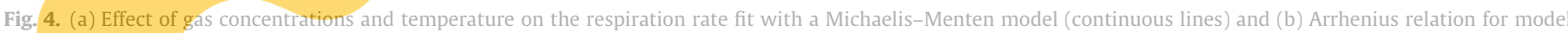
parameters of enzyme kinetics.
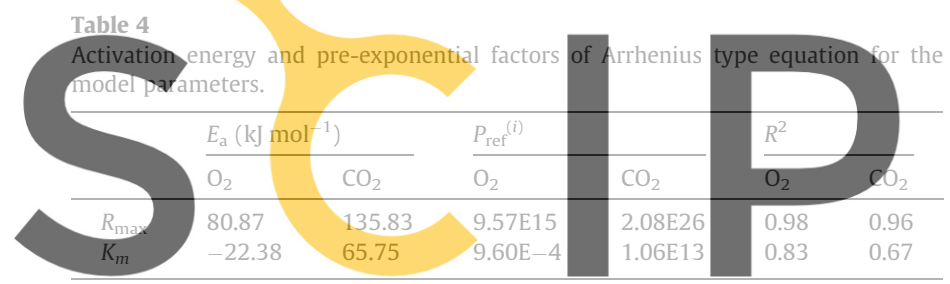
Register fomblepee at https//www.scipedia.
F-values obtained in the two-way ANovA of the pine-
apple firmness.

\begin{tabular}{ll}
\hline Factor & $\mathrm{F}$ \\
\hline Temperature $\left(4,7\right.$ or $\left.13{ }^{\circ} \mathrm{C}\right)$ & $10.443^{*}$ \\
Storage time $(2,4,6,8$ or 10 days $)$ & $6.661^{*}$ \\
Temperature $\times$ time & 1.148 \\
\hline
\end{tabular}

* Significance level: $p<0.05$.

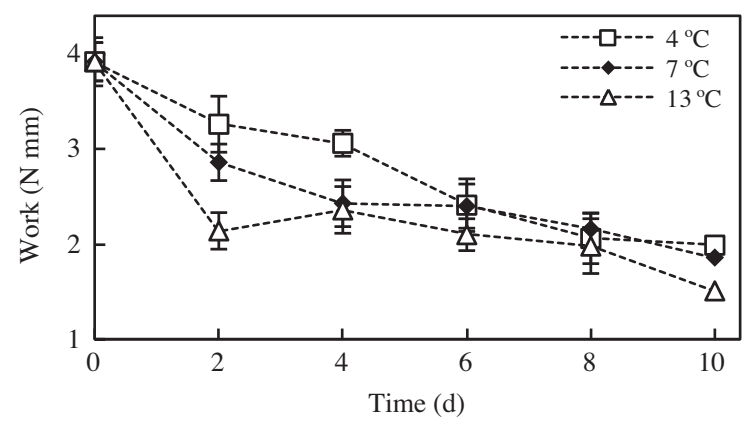

Fig. 5. Firmness of pineapple wedges over 10 days of storage at different temperatures. Vertical bars represent the mean standard error.

decrease during storage. At days 2 and 4, firmness of pineapple wedges stored at $4{ }^{\circ} \mathrm{C}$ was superior compared to the wedges stored at 7 and $13{ }^{\circ} \mathrm{C}(p<0.05)$. This texture loss is due to a decrease in cell wall turgor or to the enzymatic activity on the cell wall constitu-

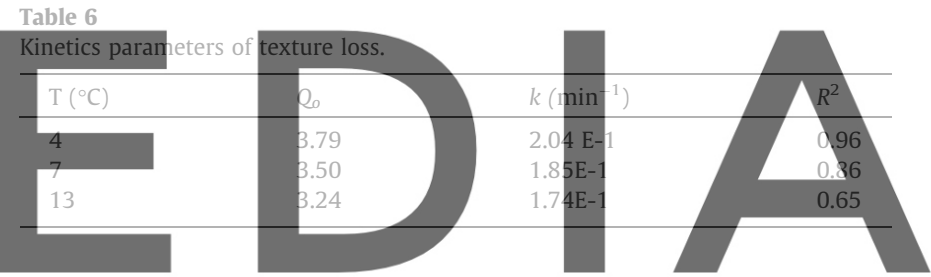

ents. The temperature dependence of the kinetic constants was cal-

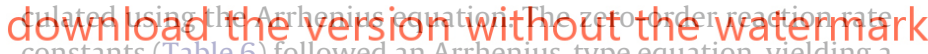
constants (Table 6) followed an Arrhenius-type equation, yielding a coefficient of determination value of 0.925 . The activation energy and pre-exponential factor were determined as $-9.55 \mathrm{~kJ} / \mathrm{mol}$ and $3.13 \mathrm{E}-3$, respectively. The negative activation energy value implies that the texture varied negatively as temperature increased.

\section{Conclusions}

The FEM was satisfactorily applied to solve the fruit-tray-environment scheme for heat exchange. The comparison between predicted and measured temperatures demonstrated the consistency of the model to correctly predict heat transfer ( RMSE $<0.34{ }^{\circ} \mathrm{C}$ ) during natural convective air-cooling. The proposed FEM heat model can help to estimate the benefits of other packaging alternatives (e.g. using a thermal insulation layer) and can generate curves for temperature evolution as a function of package characteristics (size and selected material) for a given minimally processed product. The oxygen consumption and carbon dioxide production at different temperatures can be accurately predicted through Michaelis-Menten kinetics without inhibition by $\mathrm{CO}_{2}$. Finally, the textural degradation of pineapple wedges followed zero-order kinetics and the temperature relationship was estimated using the Arrhenius equation, as well the enzymatic parameters of respiration rates.

\section{Acknowledgements}

The authors acknowledge the financial support provided by the Centro Internacional de Métodos Numéricos en Ingeniería (CIMNE). 


\section{References}

Artés, F., Gómez, P.A., Artés-Hernández, F., 2007. Physical, physiological and microbial deterioration of minimally fresh processed fruits and vegetables. Food Science and Technology International 13, 177-188.

Ávila, I.M.L.B., Silva, C.L.M., 1999. Modelling kinetics of thermal degradation of colour in peach puree. Journal of Food Engineering 39 (2), 161-166.

Bhande, S.D., Ravindra, M.R., Goswami, T.K., 2008. Respiration rate of banana fruit under aerobic conditions at different storage temperatures. Journal of Food Engineering 87 (1), 116-123.

Budu, A.S., Joyce, D.C., 2005. Effect of modified atmosphere packaging on the quality of minimally processed pineapple cv. 'smooth cayenne' fruit. Journal of Horticultural Science and Biotechnology 80 (2), 193-198.

Cantwell, M., Suslow, T.V., 2002. Postharvest handling systems: fresh-cut fruits and vegetables. In: A.A. Kader (Ed.), Postharvest Technology of Horticultural Crops, third ed., University of California, Div. Agriculture \& Natural Resources, pp. 445 463 (Pub 3311).

Cameron, A., Talasila, P., Joles, D., 1995. Predicting film permeability needs for modified-atmosphere packaging of lightly processed fruits and vegetables. HortScience: a publication of the American Society for Horticultural Science 301 (1), 25-34.

Chaiwanichsiri, S., Laohasongkram, K., Thunpithayakul, C., Mekmanee, S., 1996 Thermophysical properties of fresh and frozen pineapples. Asean Food Journal $11,1-5$.

Chen, C.R., Ramaswamy, H.S., 2002. Color and texture change kinetics in ripening bananas. Lebensmittel-Wissenschaft Und-Technologie 35 (5), 415-419.

Choi, Y., Okos, M.R., 1986. Effects of temperature and composition on the thermal properties of foods. In: Le Maguer, M., Jelen, P. (Eds.), Food Engineering and Process Applications. Elsevier Applied Science Publishers, London, UK, pp. 93101

Del Nobile, M.A. Conte, A., Scrocco, C., Brescia, I.,2009, New strategies for minimally processed cactus pear packaging. Innovative Food Science \& Emerging Technologies 10 (3), 356-362.

Eduardo, M.D.P., Benedetti, B.C., Ferraz, A.C.O., 2008. Avaliaç̃̃o de índices de firmeza para abacaxi minimamente processado em fatias tratadas com soluções de sais
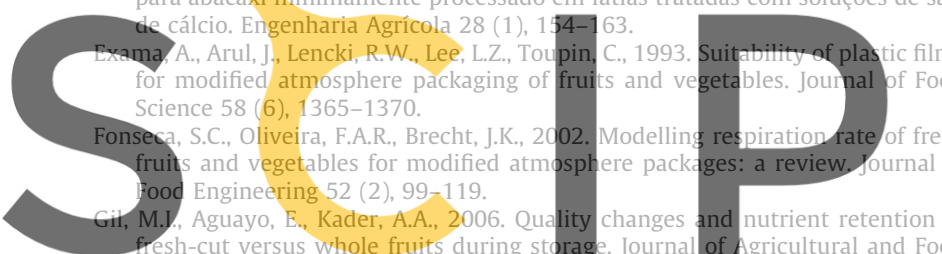

Chemistry 54 (12), 4284-4296.

Gong, S. Corey, K., 1994. Predicting steady-state oxygen concentrations in

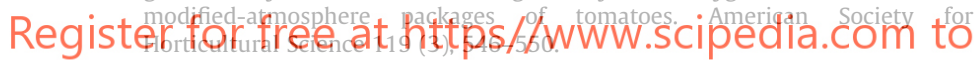

Hagger, P.E., Lee, D.S., Yam, K.L., 1992. Application of an enzyme kinetics based respiration model to closed system experiments for fresh produce. Journal of Food Process Engineering 15 (2), 143-157.

Hong, S., Kim, D., 2001. Influence of oxygen concentration and temperature on respiratory characteristics of fresh-cut green onion. International Journal of Food Science and Technology 36 (3), 283-289.

lezzi, R., Francolino, S., Mucchetti, G., 2011. Natural convective cooling of cheese: predictive model and validation of heat exchange simulation. Journal of Food Engineering 106 (1), 88-94.

Itaya, Y., Kobayashi, T., Hayakawa, K., 1995. Three-dimensional heat and moisture transfer with viscoelastic strain-stress formation in composite food during drying. International Journal of Heat and Mass Transfer 38 (7), 1173-1185.

Jacxsens, L., Devlieghere, F., De Rudder, T., Debevere, J., 2000. Designing equilibrium modified atmosphere packages for fresh-cut vegetables subjected to changes in temperature. Lebensmittel-Wissenschaft Und-Technologie 33 (3), 178-187.

Jacxsens, L., Devlieghere, F., Debevere, J., 1999. Validation of a systematic approach to design equilibrium modified atmosphere packages for fresh-cut produce. Lebensmittel-Wissenschaft Und-Technologie 32 (7), 425-432.

Lee, D.S., Lee, K.S., Park, I.S., Yam, K.L., 1994. Analysis of respiration characteristics of low $\mathrm{CO}_{2}$ tolerance produces for designing modified atmosphere package. Food Science and Biotechnology 3, 99-103.
Lee, J.J., Lee, D.S., 1996. A dynamic test for kinetic model of fresh produce respiration in modified atmosphere and its application to packaging of prepared vegetables. Food Science and Biotechnology 5, 343-348.

Liu, C., Hsu, C., Hsu, M., 2007. Improving the quality of fresh-cut pineapples with ascorbic acid/sucrose pretreatment and modified atmosphere packaging. Packaging Technology and Science 20 (5), 337-343.

Mahajan, P.V., Goswami, T.K., 2001. Enzyme kinetics based modelling of respiration rate for apple. Journal of Agricultural Engineering Research 79 (4), 399406

Mangaraj, S., Goswami, T.K., 2011. Measurement and modeling of respiration rate of guava (CV. baruipur) for modified atmosphere packaging. International Journal of Food Properties 14 (3), 609-628.

Marrero, A., Kader, A.A., 2001. Factors affecting the post-cutting life and quality of minimally processed pineapple. Acta Horticulturae 553, 705-706.

Marrero, A., Kader, A.A., 2006. Optimal temperature and modified atmosphere for keeping quality of fresh-cut pineapples. Postharvest Biology and Technology 39 (2), 163-168.

Martínez-Ferrer, M., Harper, C., 2005. Reduction in microbial growth and improvement of storage quality in fresh-cut pineapple after methyl jasmonate treatment. Journal of Food Quality 28 (1), 3-12.

McLaughlin, C.P., O'Beirne, D., 1999. Respiration rate of a dry coleslaw mix as affected by storage temperature and respiratory gas concentrations. Journal of Food Science 64 (1), 116-119.

Misra, R.N., Young, J.H., 1979. Finite element approach for solution of transient heat transfer in a sphere. Transactions of the American Society of Agricultural Engineers 22 (4), 944-949.

Montero-Calderón, M. Rojas-Graü, M.A., Martín-Belloso, O., 2008. Effect of packaging conditions on quality and shelf-life of fresh-cut pineapple (Ananas comosus). Postharvest Biology and Technology 50 (3), 182-189.

Montero-Calderón, M., Rojas-Graü, M. Martín-Belloso, O, 2010. Mechanical and chemical properties of gold cultivar pineapple flesh (Ananas comosus). European Food Research and Technology 230 (4), 675-686.

Ngadi, M.O., Watts, K.C., Correia, L.R., 1997. Finite element method modelling of moisture transfer in chicken drum during deep-fat frying. Journal of Food Engineering 32 (1), 11-20

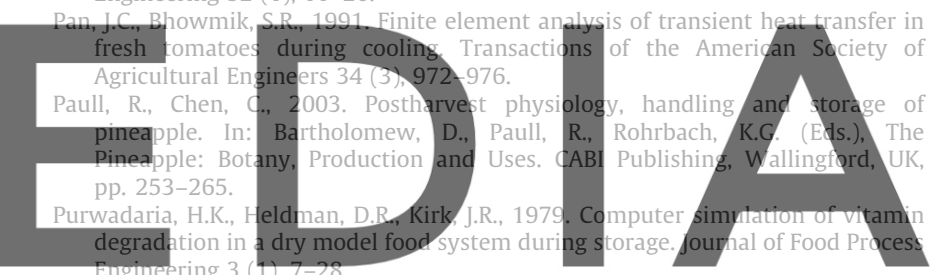

Soliva-Fortuny, R.C., Grigelmo-Miguel, N., Hernando, I., Lluch, M.Á., Martín-Belloso, 0., 2002. Effect of minimal processing on the textural and structural properties

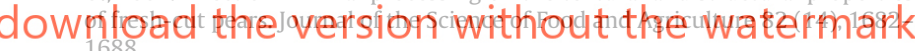

Song, Y., Kim, H.K., Yam, K.L., 1992. Respiration rate of blueberry in modified atmosphere at various temperatures. Journal of the American Society for Horticultural Science 117, 925-929.

Talasila, P.C., Chau, K.V., Brecht, J.K., 1992. Effects of gas concentrations and temperature on $\mathrm{O}_{2}$ consumption of strawberries. Transactions of the American Society of Agricultural Engineers 35, 221-224.

Taoukis, P.S., Labuza, T.P., Saguy, I.S., 1997. Kinetics of food deterioration and shelflife prediction. In: Valentas, K.J., Rotstein, E., Singh, R.P. (Eds.), Handbook of Food Engineering Practice. CRC Press, Boca Raton, Florida, pp. 361-402.

Villota, R., Hawkes, J.G., 1992. Reaction kinetics in food systems. In: Heldman, D.R., Lund, D.B. (Eds.), A Handbook of Food Engineering. Marcel Dekker, Inc., New York, pp. 39-144.

Van Boekel, M.A.J.S., 2008. Kinetic modeling of food quality: a critical review. Comprehensive Reviews in Food Science and Food Safety 7 (1), 144-158.

Wang, L., Sun, D., 2002. Modelling three-dimensional transient heat transfer of roasted meat during air blast cooling by the finite element method. Journal of Food Engineering 51 (4), 319-328.

Yam, K.L., Haggar, P.E., Lee, D.S., 1993. Modeling respiration of low $\mathrm{CO}_{2}$ tolerance produce using a closed system experiment. Food Science and Biotechnology 2 . $22-25$. 